\title{
Regulation of Polymorphonuclear Cell Activation by Thrombopoietin
}

\author{
Maria Felice Brizzi, Edda Battaglia, ${ }^{\star}$ Arturo Rosso, Pierluigi Strippoli,, Giuseppe Montrucchio, ${ }^{*}$ Giovanni Camussi,§ \\ and Luigi Pegoraro \\ Dipartimento di Medicina Interna, *Dipartimento di Fisiopatologia Clinica Università di Torino, ${ }^{*}$ Istituto di Istologia ed Embriologia, \\ Centro Interdipartimentale di Ricerca Giorgio Prodi, Università di Bologna; and ${ }^{\S}$ Istituto di Medicina e Sanità Pubblica, II Facoltà di \\ Medicina, Università di Pavia, Varese, Italy
}

\begin{abstract}
Thrombopoietin (TPO) regulates early and late stages of platelet formation as well as platelet activation. TPO exerts its effects by binding to the receptor, encoded by the protooncogene c-mpl, that is expressed in a large number of cells of hematopoietic origin. In this study, we evaluated the expression of c-Mpl and the effects of TPO on human polymorphonuclear cells (PMN). We demonstrate that PMN express the TPO receptor c-Mpl and that TPO induces STAT1 tyrosine phosphorylation and the formation of a serum inducible element complex containing STAT1. The analysis of biological effects of TPO on PMN demonstrated that TPO, at concentrations of $1-10 \mathrm{ng} / \mathrm{ml}$, primes the response of PMN to $n$-formyl-met-leu-phe (FMLP) by inducing an early oxidative burst. TPO-induced priming on FMLP-stimulated PMN was also detected on the tyrosine phosphorylation of a protein with a molecular mass of $\sim 28 \mathrm{kD}$. Moreover, we demonstrated that TPO by itself was able to stimulate, at doses ranging from 0.05 to $10 \mathrm{ng} / \mathrm{ml}$, early release and delayed synthesis of interleukin 8 (IL-8). Thus, our data indicate that, in addition to sustaining megakaryocytopoiesis, TPO may have an important role in regulating PMN activation. (J. Clin. Invest. 1997. 99:1576-1584.) Key words: thrombopoietin • signal transduction • inflammation • interleukin $8 \cdot \mathrm{c}-\mathrm{Mpl}$
\end{abstract}

\section{Introduction}

The human homologue of the v-mpl oncogene, c-mpl, encodes a member of the hematopoietic receptor superfamily that shows in the extracellular domain a high amino acid sequence homology with the erythropoietin receptor and with the common $\beta$ subunit $\left(\beta_{\mathrm{c}}\right)$ of the interleukin 3 (IL-3), interleukin 5 (IL-5), and granulocyte macrophage colony-stimulating factor (GM-CSF) receptor (1). The wide range of leukemias caused by $\mathrm{v}-\mathrm{mpl}$ and the expression of c-mpl transcript in a large number of cells of hematopoietic origin (2) strongly suggested that c-mpl could play a functional role in hematopoiesis. Direct evi-

M.F. Brizzi and E. Battaglia contributed equally to this work.

Address correspondence to Dr. Luigi Pegoraro, Dipartimento di Medicina Interna, Corso Dogliotti 14, 10126 Torino, Italy. FAX: 3911-663-7520.

Received for publication 15 July 1996 and accepted in revised form 22 January 1997.

J. Clin. Invest.

(C) The American Society for Clinical Investigation, Inc. 0021-9738/97/04/1576/09 \$2.00

Volume 99, Number 7, April 1997, 1576-1584 dence that the c-mpl is involved in hematopoiesis has been provided recently by several groups, with its identification and with the cloning of its ligand (3). The in vitro and in vivo biological effects of c-Mpl ligand, also termed thrombopoietin (TPO) ${ }^{1}$ demonstrated that this cytokine has thrombopoietic and megakaryocytopoietic functions (3-7). In addition, recent studies have shown that TPO can directly modulate the response of platelets to several stimuli and can thereby modulate their hemostatic potential (8-10). Although TPO has been defined as a lineage-specific late-acting growth factor, early works reported that this factor also exerts a minimal effect on the erythroid and granulocytic population (5). Moreover, the observation that early hemopoietic progenitor cells express c-mpl (11) and the recent demonstration that TPO also has the ability to enhance the proliferation of early erythroid progenitors (12) and to directly affect erythroid differentiation (13) suggest that TPO can also play a role outside the megakaryopoietic lineage.

It is known that hemopoietic growth factors, in addition to supporting proliferation and differentiation of hemopoietic progenitors (14), play an important role in host defense by enhancing the functional activity of mature leukocytes (15). On the PMN, for instance, GM-CSF induces surface expression of both chemotactic receptors and adherence proteins (16) as well as oxygen radical production (15). Moreover, GM-CSF and G-CSF also exert indirect effects on PMN by priming these cells for enhanced responses to a variety of inflammatory agonists (15). Biochemical studies have demonstrated that the tyrosine phosphorylation of intracellular molecules and the activation of tyrosine kinases play an important role in mediating PMN functional activation induced both by physiological agonists and growth factors (17).

c-Mpl receptor, which belongs to the hemopoietic growth factor receptor superfamily (1), is devoid of intrinsic tyrosine kinase activity. However, ligand binding characteristically induces tyrosine phosphorylation of multiple intracellular proteins, a requisite event for the initiation of signal transduction (18). As with other related hematopoietic growth factor receptors, ligand-activated c-Mpl triggers the phosphorylation of several transducing molecules, including Vav, c-Cbl, PI-3 kinase (19), MAPK (8), Shc, and its association with Grb2 (20, 21), JAK2 (20-22), and members of the signal transduction and activators of transcription (STATs) STAT1, STAT3, and STAT5 (19-24).

The aim of this study was to investigate the effects of TPO on PMN functional activation. We found that PMN express $\mathrm{c}-\mathrm{Mpl}$ and that TPO induces in these cells the formation of a serum inducible element (SIE) complex containing STAT1

1. Abbreviations used in this paper: SIE, serum inducible element; TPO, thrombopoietin. 
but not STAT3. Moreover, we demonstrated that TPO primes the response of PMN to $n$-formyl-met-leu-phe (FMLP) by inducing an early oxidative burst with production of several $\mathrm{O}_{2}^{-}$ metabolites, and that TPO, by itself, stimulates PMN to release and to produce interleukin 8 (IL-8).

\section{Methods}

Reagents. RPMI 1640 medium (Gibco Laboratories, Grand Island, NY) and bovine calf serum were from Hyclone Laboratories (Logan, UT). Gelatin was from Difco Laboratories, Inc. (Detroit, MI). TPO and EGF were from Genzyme Corp. (Cambridge, MA). The Sepharose-protein A was purchased from Sigma Chemical Co. (St. Louis, MO). Nitrocellulose filters, horseradish peroxidase-conjugated protein $\mathrm{A}$, molecular weight markers, $\left[\alpha{ }^{32} \mathrm{P}\right] \mathrm{dCTP}$, and the chemiluminescence reagent (ECL) were from Amersham Corp. (Arlington Heights, IL). Poly(dIdC):poly(dIdC) was obtained from Pharmacia (Uppsala, Sweden). Ferricytochrome $c$ (type IV), superoxide dismutase, phenol red, horseradish peroxidase, luminol, lipopolysaccharide, and FMLP were purchased from Sigma Chemical Co.

Antisera. Affinity-purified polyclonal anti-c-Mpl antibody was prepared from serum of a rabbit immunized against a GST-fusion protein, containing the amino acid sequence corresponding to residues 519-568 (GenBank accession No. M90102), as described previously (25). The cDNA encoding the GST-fusion protein with the intracytoplasmic portion of the $\mathrm{c}-\mathrm{Mpl}$ was generated by ligating the PCR fragment, which introduces a novel restriction endonuclease site EcoRI of the c-mpl, into the EcoRI site of pGEX-5X vector (Pharmacia Biotech Inc., Alameda, CA).The oligonucleotides, used to introduce the novel restriction endonuclease site EcoRI of the c-mpl, were TGG CAG TTT CCT GAA TTC TAC AGG AGA CT and CTT GGG GAG GAA TTC $\overline{\mathrm{AAG}} \overline{\mathrm{GAG}}$ GCT. The GST-fusion proteins were expressed in Escherichia coli, and protein was purified as described (26). Polyclonal antibodies to $\mathrm{p} 91$ were produced in rabbits by injection with a synthetic peptide corresponding to the sequences of 84-96 residues of human transcription factor ISGR-3 (accession No. M97935): RKSKRNLQDNFQEDC (27). The 4G10 and PY20 antiphosphotyrosine antibodies were obtained from Upstate Biotechnology, Inc. (Lake Placid, NY) and from Affinity Research Products Ltd. (Nottingham, United Kingdom), respectively. Anti-STAT3 antiserum was purchased from Affinity Research Products Ltd.

Cells. Human PMN were isolated from venous blood of healthy donors by gelatin sedimentation (2.5\% gelatin in PBS, $\mathrm{pH} 7.2$, for 30 min at $37^{\circ} \mathrm{C}$ ) followed by Ficoll-Hypaque gradient separation. Contaminating erythrocytes were removed by hypotonic lysis and the cells were resuspended in RPMI 1640 medium at the final concentration of $1 \times 10^{6} / \mathrm{ml}$. The percentage of neutrophils in cell preparation used in this study was $95-97 \%$. The cell viability as determined by trypan blue exclusion was 96-98\%. A431 cells were maintained in RPMI 1640 medium supplemented with $10 \%$ bovine calf serum and serumstarved overnight before being treated with rhEGF $(100 \mathrm{ng} / \mathrm{ml})$.

Western blot analysis and immunoprecipitation studies. PMN $(40 \times$ $\left.10^{6}\right)$ were preincubated for $2 \mathrm{~min}$ with or without TPO $(10 \mathrm{ng} / \mathrm{ml})$ and then incubated with FMLP (100 nmol/liter) or the vehicle alone at $37^{\circ} \mathrm{C}$ for 2 or $5 \mathrm{~min}$. In selected experiments PMN were pretreated with vanadate $(200 \mu \mathrm{mol} /$ liter $)$ for $10 \mathrm{~min}$ before the incubation with TPO and FMLP. PMN were then extracted with cold DIM buffer (50 $\mathrm{mmol} /$ liter Pipes, pH 6.8, $100 \mathrm{mmol} /$ liter $\mathrm{NaCl}, 5 \mathrm{mM} \mathrm{MgCl}, 300$ $\mathrm{mmol} /$ liter sucrose, $5 \mathrm{mmol} /$ liter EGTA, $2 \mathrm{mmol} /$ liter sodium orthovanadate) plus $1 \%$ Triton $\mathrm{X}-100$ and a mixture of protease inhibitors ( $1 \mathrm{mmol} / \mathrm{liter}$ PMSF, $10 \mu \mathrm{g} / \mathrm{ml}$ leupeptin, $0.15 \mathrm{U} / \mathrm{ml}$ aprotinin, $1 \mu \mathrm{g} / \mathrm{ml}$ pepstatin A) for $20 \mathrm{~min}$ at $4^{\circ} \mathrm{C}$, and centrifuged at $15,000 \mathrm{~g}$ for $20 \mathrm{~min}$. The clarified supernatant was precleaned for $1 \mathrm{~h}$ with $50 \mu \mathrm{l}$ of Sepharose-protein A (3 mg/sample). The protein concentration of PMN lysates was determined by the Bradford technique and the protein content of the samples was normalized to $250 \mathrm{mg} / \mathrm{sample}$ by appropriate dilution with the cold DIM buffer. The samples were then adsorbed by antisera coupled to Sepharose-protein A. Bound proteins were washed several times in DIM buffer and eluted in boiling Laemmli buffer. $30 \mu \mathrm{l}$ of eluted proteins was subjected to $8 \%$ SDSPAGE. Proteins were then transferred electrophoretically to nitrocellulose; the filters were incubated with blocking solution $(10 \%$ low fat milk in $20 \mathrm{mmol} /$ liter Tris- $\mathrm{HCl}, \mathrm{pH} 7.6$, and $17 \mathrm{mmol} /$ liter $\mathrm{NaCl}$ ) for $1 \mathrm{~h}$. Antisera were then added at the same solution, and the incubation was carried out for $2 \mathrm{~h}$ at room temperature. For detection, the filters were washed three times (10 min each wash) with PBS, $0.05 \%$ Tween 20 and reacted for $1 \mathrm{~h}$ at room temperature with horseradish peroxidase-conjugated protein A. The enzyme was removed by washing as above. The filters were reacted for 1 min with a chemiluminescence reagent (ECL) and exposed to an autoradiography film for 1-15 min. To reprobe, nitrocellulose filters were first stripped of antibody by $62 \mathrm{mmol} / \mathrm{liter}$ Tris-HCl, pH 6.7, 2\% SDS, $100 \mathrm{mmol} / \mathrm{liter}$ B2-mercaptoethanol.

Preparation of nuclear extract and gel retardation assay. Nuclear extracts from untreated and TPO-treated PMN and from untreated and EGF-treated A431 cells were prepared by Nonidet P-40 lysis as described by Sadowski and Gilman (28). The oligonucleotides used were G GGG CAT TTC CCG TAA ATC and G GGG GAT TTA CGG GAA ATG (27). The annealed oligonucleotide was labeled by filling in the overhanging ends with Klenow fragment in the presence of $\left[\alpha{ }^{32} \mathrm{P}\right] \mathrm{dCTP}$. Gel retardation reactions were performed in $13 \mathrm{mmol} /$ liter Hepes, $\mathrm{pH}$ 7.6, $80 \mathrm{mmol} /$ liter $\mathrm{NaCl}, 3 \mathrm{mmol} /$ liter $\mathrm{NaF}$, $3 \mathrm{mmol} /$ liter $\mathrm{NaMoO}_{4}, 1 \mathrm{mmol} /$ liter DTT, $0.15 \mathrm{mmol} /$ liter EDTA, $0.15 \mathrm{mmol} /$ liter EGTA, and $8 \%$ glycerol (including contribution from the nuclear extract) and contained $75 \mu \mathrm{g} / \mathrm{ml}$ poly(dIdC):poly(dIdC), $\sim 0.3 \mathrm{ng}$ of radiolabeled probe, and 5-10 $\mu \mathrm{g}$ of protein. Reactions were carried on at room temperature for $40 \mathrm{~min}$ and then resolved on $4 \%$ polyacrylamide gels containing $0.25 \times \mathrm{TBE}(1 \times \mathrm{TBE}$ is $89 \mathrm{mmol} /$ liter Tris borate, $1 \mathrm{mmol} /$ liter EDTA, $\mathrm{pH} 8$ ) and $5 \%$ glycerol. Gels were run at $4^{\circ} \mathrm{C}$ in $0.25 \times \mathrm{TBE}$ at $20 \mathrm{~V} / \mathrm{cm}$, dried, and autoradiographed. Oligonucleotide competition was performed by preincubating nuclear extracts with the competitor oligonucleotide (50-fold excess) and poly(dIdC):poly(dIdC) for $30 \mathrm{~min}$ at room temperature before the addition of labeled probe. Gel mobility-shift assays were done with nuclear extract that had been reacted for $1 \mathrm{~h}$ at $4^{\circ} \mathrm{C}$ with the indicated antibodies.

Experimental protocol. The direct effect of TPO on the production of oxygen metabolites or IL- 8 by human PMN was evaluated. In the absence of direct effect, as in the case of the production of oxygen metabolites, the ability of TPO to prime PMN response to FMLP was also evaluated. The priming effect of TPO was evaluated $(a)$ in experiments of costimulation where TPO and FMLP were mixed within the experimental vials immediately before the addition of PMN and (b) in experiments where TPO was preincubated with PMN for various periods of time before the addition of FMLP. The priming index (PI) was calculated, as previously described (8), as the response to TPO and FMLP together divided by the sum of the individual stimulus response. By this calculation, $\mathrm{PI}>1$ indicates synergism, $\mathrm{PI}=1$ indicates additive response, and $\mathrm{PI}<1$ indicates inhibition.

Superoxide anion $\left(\mathrm{O}_{2}^{-}\right)$assay. Production of $\mathrm{O}_{2}^{-}$was measured as the superoxide dismutase inhibitable reduction of ferricytochrome c. PMN were incubated at $37^{\circ} \mathrm{C}$ with Tyrode's buffer containing 80 $\mathrm{mM}$ cytochrome $c$ and appropriately stimulated at the specified time. Basal $\mathrm{O}_{2}^{-}$production was assessed in the absence of stimulating factors. Supernatants were removed and centrifuged, and the absorbance was measured in a spectrophotometer at $550 \mathrm{~nm}$. The extinction coefficient of ferricytochrome $c$ at $550 \mathrm{~nm}$ was taken as $2.1 \times 10^{4}$ $\mathrm{M}^{-1} \mathrm{~cm}^{-1}$. Protein content of the PMN was measured by the Lowry technique. $\mathrm{O}_{2}^{-}$production was expressed as $\mathrm{nM}$ of cytochrome $c$ reduced/mg protein/time (29).

Chemiluminescence. Luminol $(50 \mathrm{mM})$ enhanced chemiluminescence was measured on $2 \times 10^{6} \mathrm{PMN}$ suspended in Hepes-buffered Krebs medium containing $0.05 \%$ BSA using an LKB 1250 luminometer. Data are expressed in $\mathrm{mV}(30)$.

Determination of $I L-8$. PMN were incubated with stimuli at $37^{\circ} \mathrm{C}$ 
and supernatants were recovered after various times. The quantitative determination of IL-8 in supernatant was performed by ELISA using the Cytoscreen Human IL-8 kit (KHC0082; BioSource International, Camarillo, CA).

Statistical analysis. All data within groups were analyzed by oneway ANOVA with Dunnett's or Newman-Keul's multiple comparison test when appropriate. Values were given as mean \pm SD. Values of $P<0.05$ were considered statistically significant.

\section{Results}

PMN express the TPO receptor. Previous studies have shown that TPO receptor, $\mathrm{c}-\mathrm{Mpl}$, is expressed in the megakaryocytic lineage from late progenitors to platelets as well as in a few leukemic cell lines (31). The observations that TPO effects are not restricted to the megakaryocytic lineage $(32,33)$ suggest that c-Mpl may be expressed in other cell types of the hemopoietic system. In this study, we first evaluated c-Mpl expression in PMN. Cell lysates from PMN or platelets were immunoprecipitated with an anti-c-Mpl antiserum raised against the intracellular domain of the receptor or with a preimmune serum. The eluted proteins were subjected to $8 \%$ SDS-PAGE and the filter was immunoblotted with the same antiserum. The results shown in Fig. 1 demonstrate that the anti-c-Mpl antiserum was able to recognize TPO receptor both in platelets and in PMN but not in platelets that were immunoprecipitated with the preimmune serum.

TPO induces STAT1 tyrosine phosphorylation in human $P M N$. Previous studies have shown that TPO activates JAKSTAT signal transduction pathway both in a human growth factor-dependent cell line and in platelets $(21,22)$. To assess whether STAT1 was also activated in TPO-treated PMN, unstimulated and TPO-stimulated cells were immunoprecipitated with anti-STAT1 antiserum. The results of the experiments reported in Fig. $2 A$ demonstrated that treatment of mature PMN with TPO induces STAT1 tyrosine phosphorylation. Moreover, kinetic analysis demonstrated that both tyrosine phosphorylation and dephosphorylation were rapid since STAT1 tyrosine phosphorylation was evident after 5 min of incubation with TPO and was completely abrogated after 15 min (Fig. $2 \mathrm{~B}$ ). The effect of TPO was dose dependent as it became detectable at the dose of $0.1 \mathrm{ng} / \mathrm{ml}$ and reached its maximum at the dose of $10 \mathrm{ng} / \mathrm{ml}$ (data not shown).

Formation of DNA-protein complex in nuclear extract of TPO-treated and untreated PMN. We have demonstrated pre-

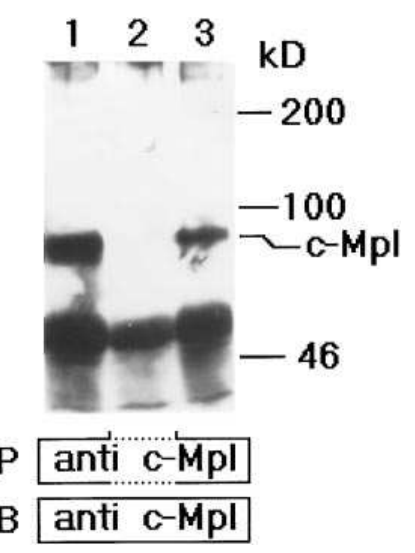

Figure 1. PMN express the TPO receptor c-Mpl. Platelets were lysed and immunoprecipitated with the anti-c-Mpl antiserum or a preimmune serum (lanes 1 and 2, respectively). Cell lysates from PMN $\left(10^{8}\right)$ were immunoprecipitated with the anti-c-Mpl antiserum (lane $3)$. The eluted proteins were subjected to $8 \%$ SDS-PAGE and the filter was immunoblotted with the anti-c-Mpl antiserum. The position of $\mathrm{c}-\mathrm{Mpl}$ is indicated by the arrow. $I P$, immunoprecipitated; $I B$, immunoblotted.
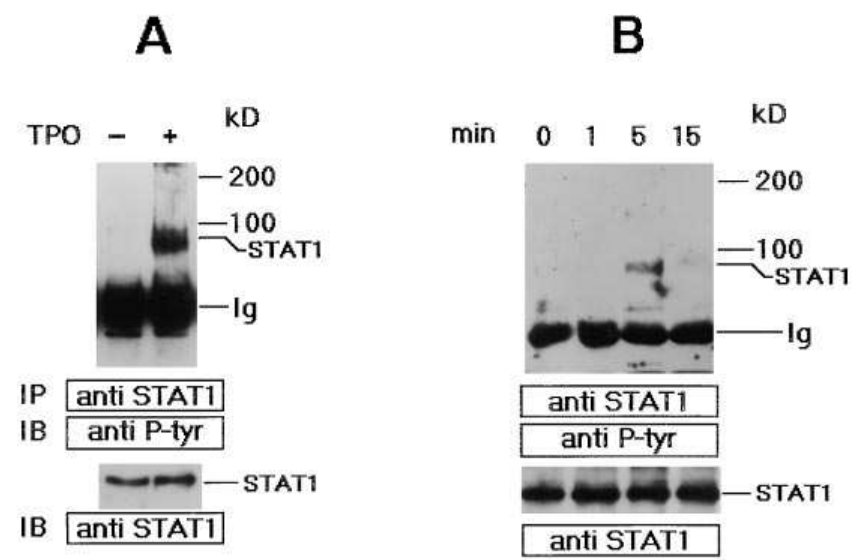

Figure 2. Tyrosine phosphorylation and kinetic analysis of TPOinduced STAT1 activation in human PMN. $(A)$ PMN were incubated in RPMI 1640 medium in the absence or in the presence of TPO $(10 \mathrm{ng} / \mathrm{ml})$ for $5 \mathrm{~min}$, lysed, and immunoprecipitated with the antiSTAT1 antiserum. The filter was probed with 4G10 antiphosphotyrosine monoclonal antibody (top) and reprobed with the antiserum against STAT1 (bottom). (B) PMN were incubated in RPMI 1640 medium in the absence or in the presence of TPO $(10 \mathrm{ng} / \mathrm{ml})$ for the indicated time, lysed, and immunoprecipitated with the anti-STAT1 antiserum. The filter was probed with 4G10 antiphosphotyrosine monoclonal antibody (top ) and reprobed with the antiserum against STAT1 (bottom). The positions of the STAT1 are indicated. IP, immunoprecipitated; $I B$, immunoblotted; $P$-tyr, phosphotyrosine.

viously that, in PMN, GM-CSF induces STAT1 and STAT3 tyrosine phosphorylation and the formation of a DNA-protein complex with the SIE of c-fos containing both STATs proteins (27). Gurney et al. demonstrated that TPO is also able to induce c-fos gene transcription by activating STAT proteins (20). The tyrosine phosphorylation of STAT1 observed in TPO-stimulated PMN prompted us to evaluate, by gel retardation assay, the formation of SIE complex in nuclear extracts from untreated and TPO-treated PMN. The results reported in Fig. $3 \mathrm{~A}$ demonstrate the presence of a band of SIE binding activity that could be specifically blocked by competition with unlabeled SIE (Fig. $3 A$ ), but not by other unrelated oligonucleotides (data not shown). To extend the above data, supershifted experiments were performed with antibodies against STAT1 and STAT3 to determine whether one or both proteins were present in TPO-induced SIE complex. As shown in Fig. $3 B$, the supershifted assay demonstrated that the TPOinduced complex did not react with STAT3. By contrast, the anti-STAT1 antibody altered the apparent mobility of the DNA-protein complex, indicating the presence of an immunoreactive STAT1 protein in the extract of TPO-treated PMN. The addition of both anti-STAT1 and STAT3 antibodies to the nuclear extracts from EGF-stimulated A431 cells used as control altered the mobility of the EGF-induced complex, as reported previously (34).

Effect of TPO and FMLP on the production of oxygen metabolites. TPO by itself did not induce significant generation of oxygen-derived metabolites at all concentrations tested $(0.5-15 \mathrm{ng} / \mathrm{ml})$. However, when added concomitantly with FMLP, TPO induced a rapid enhancement of chemiluminescence and $\mathrm{O}_{2}^{-}$production by PMN. As shown in Fig. 4, the priming effect was dose dependent. The minimal priming dose 


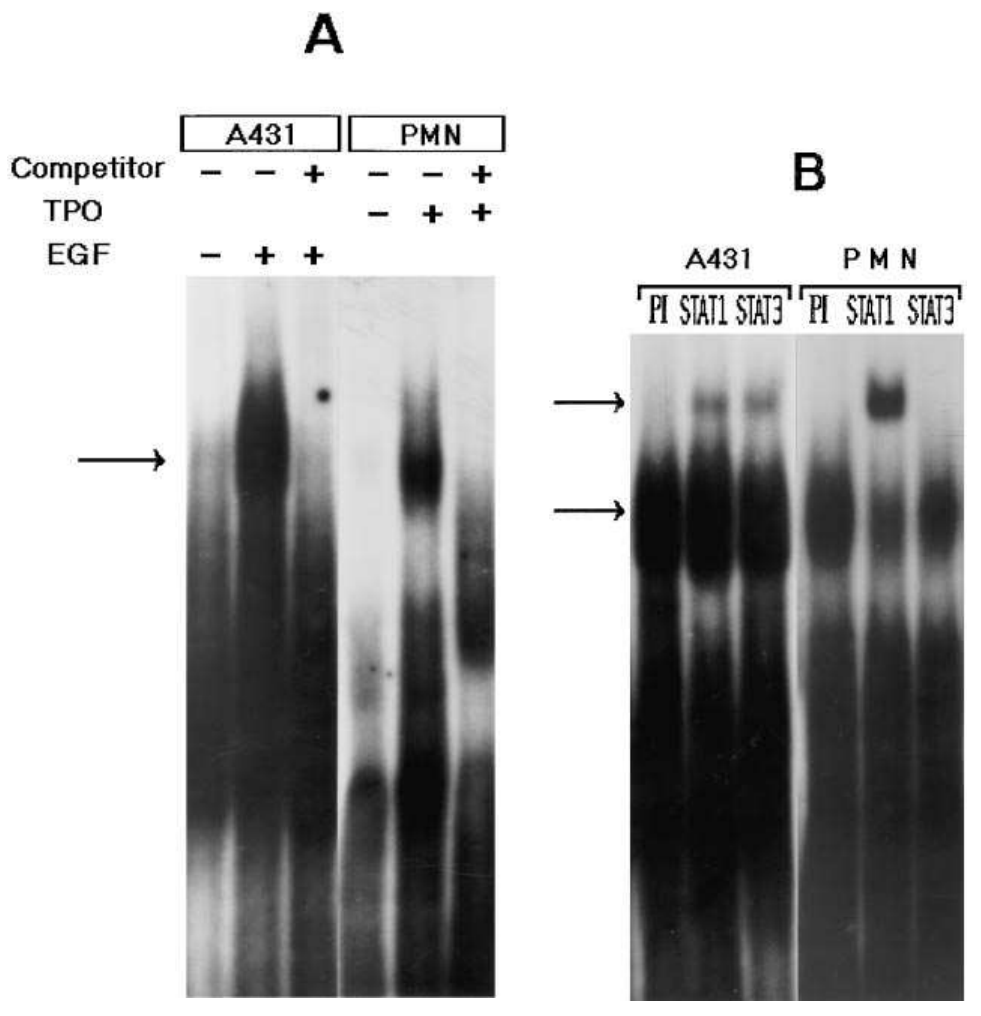

Figure 3. (A) Induction of SIE-binding activity by TPO and EGF in PMN and in A431 cells, respectively. Nuclear extracts of untreated $(-)$ or 15 -min EGF-treated A431 cells and TPO-treated PMN $(+)$ were either treated $(+)$ or not treated $(-)$ with 50 -fold excess of unlabeled oligonucleotide (competitor) for $30 \mathrm{~min}$ before the addition of radiolabeled oligonucleotide. The complexes were then resolved by nondenaturing polyacrylamide gel electrophoresis. The DNAbinding complexes are indicated. $(B)$ The TPO-induced SIE complex is antigenically related to STAT1. Nuclear extracts from 15-min TPO-treated PMN or EGF-treated A431 cells were preincubated for $1 \mathrm{~h}$ at $4^{\circ} \mathrm{C}$ with preimmune serum $(P I)$, anti-STAT1, or anti-STAT3 antisera before incubation with radiolabeled oligonucleotide and separated on a nondenaturing polyacrylamide gel electrophoresis. The EGF- and TPO-induced SIE complexes and the supershifted species are indicated.

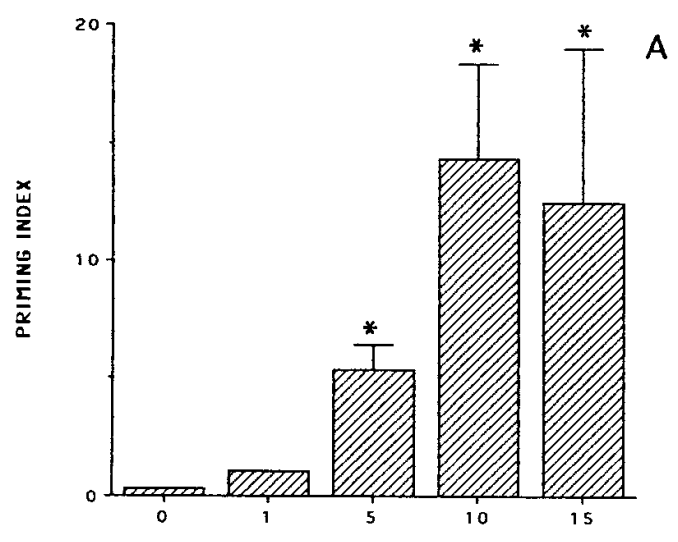

TPO $(n g / m l)$

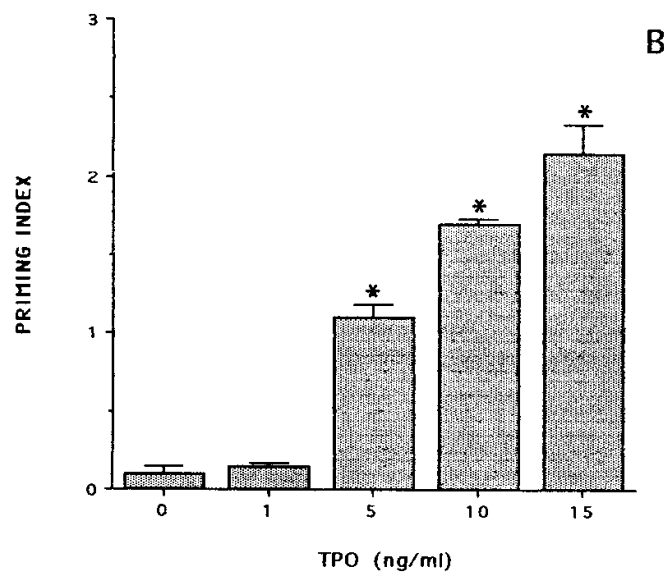

B of TPO in costimulatory experiments with FMLP was $5 \mathrm{ng} / \mathrm{ml}$. Priming reached a plateau at $10 \mathrm{ng} / \mathrm{ml}$. Moreover, by increasing the time of preincubation with TPO, an enhancement of PMN priming was observed (Fig. 5). Indeed, the minimal priming dose of TPO was found to be $1 \mathrm{ng} / \mathrm{ml}$ after pretreatment of PMN for 15 or $30 \mathrm{~min}$. All these effects of TPO were abrogated by $5 \mathrm{~min}$ of boiling. The priming was never observed when PMN were incubated with the vehicle alone instead of TPO (Fig. 4). Since previous studies with vanadate and genistein have implicated tyrosine phosphorylation/dephosphorylation in the regulation of $\mathrm{O}_{2}^{-}$release, we evaluated the effects of these agents on TPO-induced priming of $\mathrm{O}_{2}^{-}$release. The results obtained indicate that the priming effects of TPO on the release of $\mathrm{O}_{2}^{-}$by PMN stimulated with FMLP was abrogated by pretreatment with genistein, which inhibits tyrosine kinase activity (35) and was potentiated by vanadate, which inhibits tyrosine phosphatases (36) (Fig. 6).

Figure 4. Priming effect of TPO on the production of oxygen metabolites. (A) Priming effect on chemiluminescence of various doses (ng/ $\mathrm{ml} ; 0 \mathrm{ng} / \mathrm{ml}$ indicates incubation with vehicle alone) of TPO on PMN coincubated with $100 \mathrm{nM}$ FMLP. Data (mean \pm SE of six experiments) are expressed as priming index (see Methods) evaluated on the chemiluminescence recorded 5 min after stimulation. (B) Priming effect on $\mathrm{O}_{2}^{-}$production of various doses $(\mathrm{ng} / \mathrm{ml} ; 0 \mathrm{ng} / \mathrm{ml}$ indicates incubation with vehicle alone) of TPO on PMN coincubated with 100 $n M$ FMLP. Data (mean \pm SE of six experiments) are expressed as priming index (see Methods) evaluated on the $\mathrm{O}_{2}^{-}$production detected 1 min after stimulation. ANOVA with Dunnett's comparison test was performed within the experimental groups of PMN not incubated and the experimental groups of PMN incubated with TPO $\left({ }^{*} P<0.05\right)$. 

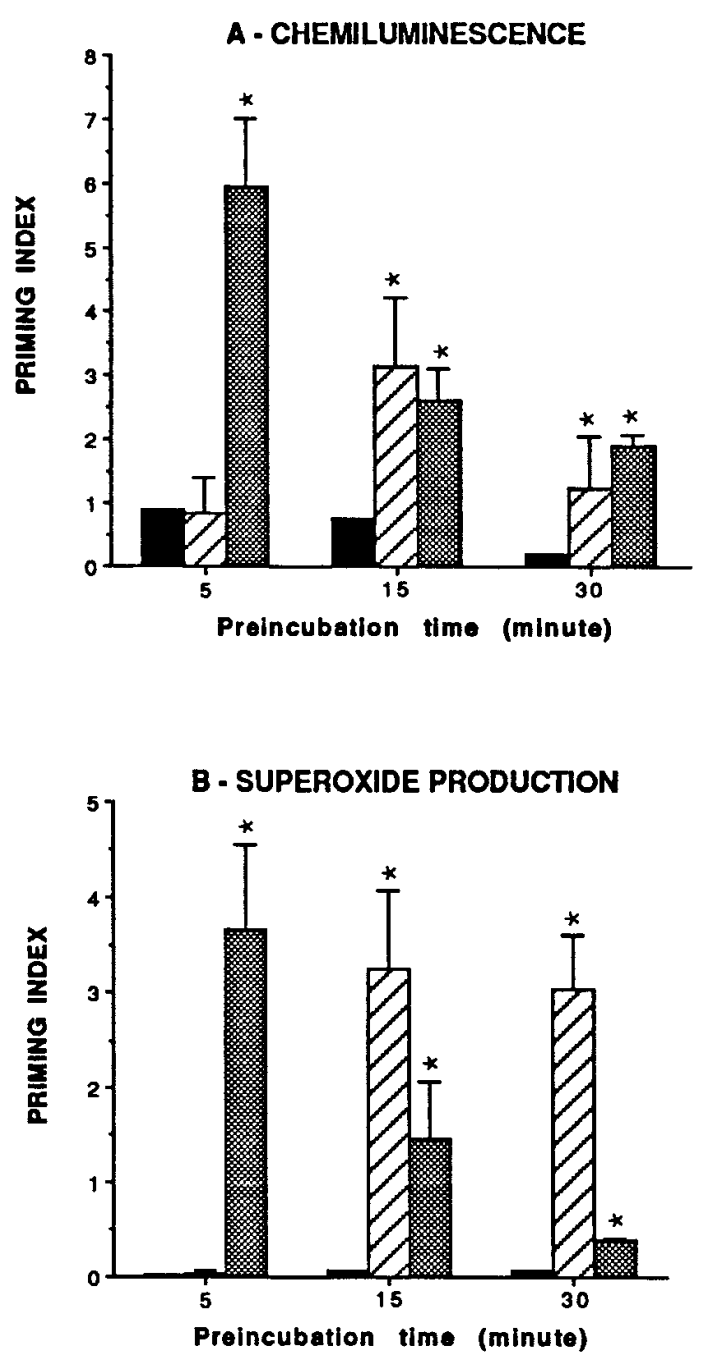

Figure 5. Effect of time of preincubation with TPO on the production of oxygen metabolites. $(A)$ Effect of various times of TPO preincubation on TPO-induced priming on chemiluminescence of PMN stimulated with $100 \mathrm{nM}$ FMLP. Data (mean \pm SE of three experiments) are expressed as priming index (see Methods) evaluated on the chemiluminescence recorded $5 \mathrm{~min}$ after stimulation. $(B)$ Effect of various times of TPO preincubation on TPO-induced priming on $\mathrm{O}_{2}^{-}$production by PMN stimulated with $100 \mathrm{nM}$ FMLP. Data (mean \pm SE of three experiments) are expressed as priming index (see Methods) evaluated on the $\mathrm{O}_{2}^{-}$production detected 1 min after stimulation. ANOVA with Dunnett's multiple comparison test was performed within the experimental groups of PMN not incubated and the experimental groups of PMN incubated with TPO $(* P<0.05)$. Black bars, TPO 0.5; striped bars, TPO 1; stippled bars, TPO 5.

Effect of FMLP and TPO on p28 tyrosine phosphorylation in $P M N$. The above results demonstrate that TPO, like other growth factors, exerts a priming effect on FMLP-induced PMN oxygen metabolites generation. It has been reported that in PMN physiological agonists and growth factors activate a similar pattern of protein tyrosine phosphorylation (37), suggesting that the priming effects exerted by a given growth factor may be due to the activation of signaling protein(s) that also mediate the agonist effect. To validate this possibility we evaluated the effects of FMLP and TPO alone or in combination on protein tyrosine phosphorylation by antiphosphotyrosine

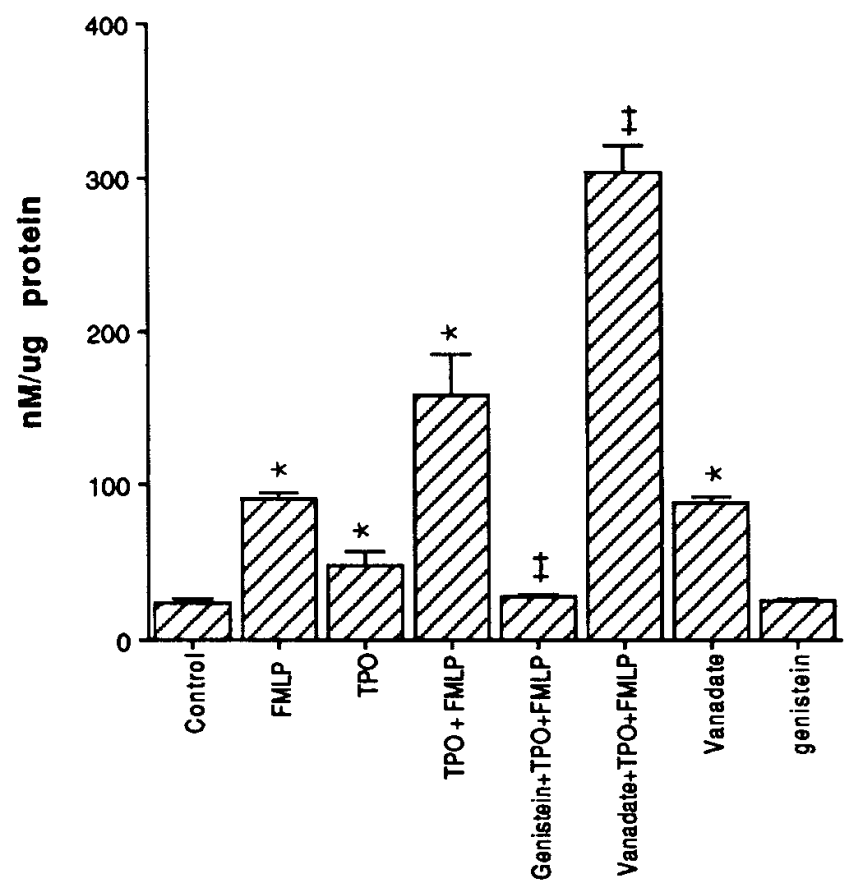

Figure 6. Effect of genistein and vanadate on TPO-induced priming on superoxide production. PMN were preincubated for $10 \mathrm{~min}$ at $37^{\circ} \mathrm{C}$ with $10 \mu \mathrm{M}$ genistein or $200 \mu \mathrm{M}$ vanadate and then costimulated with $15 \mathrm{ng} / \mathrm{ml}$ TPO and $100 \mathrm{nM} \mathrm{FMLP}$. Data (mean \pm SE of four experiments) are expressed as $\mathrm{nM} / \mathrm{ng}$ proteins of $\mathrm{O}_{2}^{-}$production of $1 \times 10^{6}$ cells detected $1 \mathrm{~min}$ after stimulation. ANOVA with Newman Keul's multiple comparison test was performed within control versus FMLP, TPO and TPO + FMLP, genistein + TPO + FMLP, vanadate + TPO + FMLP, genistein alone, and vanadate alone $(* P<$ $0.05) ; \mathrm{TPO}+$ FMLP versus genistein and vanadate PMN treated with genistein and vanadate, then incubated with TPO + FMLP $\left({ }^{\ddagger} P<0.05\right)$.

immunoprecipitation experiments. As shown in Fig. $7 \mathrm{~A}$, both FMLP and TPO stimulated the tyrosine phosphorylation of a protein with an apparent molecular mass of $28 \mathrm{kD}$. When PMN were incubated with TPO for 2 min before the stimulation with FMLP, the band of immunoprecipitated tyrosine phosphorylated p28 protein was markedly increased. Time course experiments demonstrated that the tyrosine phosphorylation was rapid and transient since it was maximal 2 min after stimulation with FMLP and was almost completely abolished after $5 \mathrm{~min}$ (Fig. $7 \mathrm{~B}$ ). Vanadate was shown to determine a persistent increase of p28 tyrosine phosphorylation (Fig. 8), suggesting that the rapid decrease in p28 tyrosine phosphorylation observed at 5 min (Fig. $7 \mathrm{~B}$ ) was dependent on a tyrosine phosphatase activity. Genistein $(10 \mu \mathrm{M})$ prevented the phosphorylation of the p28 protein (data not shown). These results suggest that p28 may be a target protein for both FMLP- and TPO-induced tyrosine phosphorylation.

Effect of TPO on the production of IL-8 by PMN. IL-8 is produced and released by PMN after exposure to TPO. As shown in Fig. $9 A$, TPO induced synthesis and release of IL- 8 in a dose-dependent manner. The minimal effective dose of TPO was $0.05 \mathrm{ng} / \mathrm{ml}$. As for FMLP, an early release of preformed IL- 8 was observed $2 \mathrm{~h}$ after challenge with TPO. While the release of IL- 8 induced by FMLP was significantly de- 


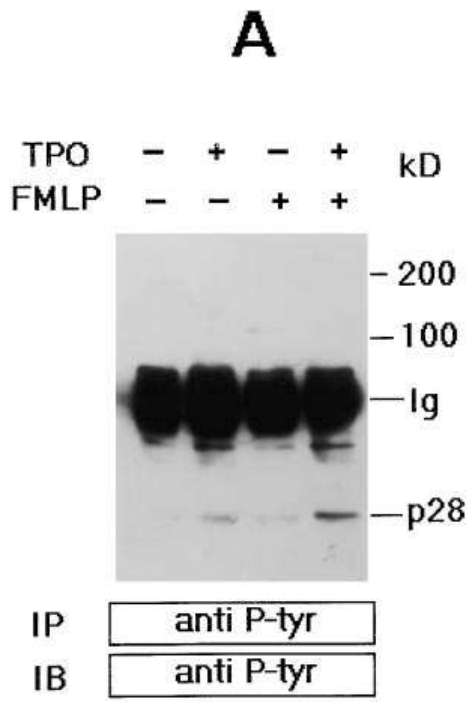

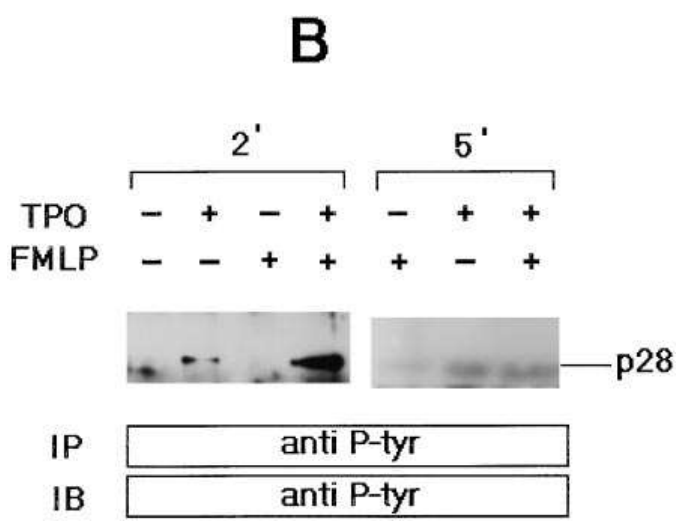

Figure 7. (A) FMLP- and TPO-induced tyrosine phosphorylation in human PMN. Cell lysates from unstimulated $(-)$ and TPO-stimulated $(10 \mathrm{ng} / \mathrm{ml})$ or FMLP-stimulated (100 nmol/liter) (alone or in combination) $(+)$ PMN were immunoprecipitated with antiphosphotyrosine antibody. The filter was probed with $4 \mathrm{G} 10$ antiphosphotyrosine monoclonal antibody. $(B) \mathrm{Ki}$ netic analysis of TPO- and FMLP-induced tyrosine phosphorylation. Cell lysates from unstimulated ( - ) and 2 or 5 min FMLP(100 nmol/liter) or TPO-stimulated (10 ng/ $\mathrm{ml})$ (alone or in combination) (+) PMN were immunoprecipitated with antiphosphotyrosine antibody. The filter was probed with $4 \mathrm{G} 10$ antiphosphotyrosine monoclonal antibody. The positions of the phosphotyrosine $\mathrm{p} 28$ are indicated. $I P$, immunoprecipitated; $I B$, immunoblotted; $P$-tyr, phosphotyrosine. creased at $12 \mathrm{~h}$, the effect of TPO was sustained and persisted, suggesting a neosynthesis of this chemokine (Fig. $9 \mathrm{~B}$ ). No significant release of IL-8 was observed when PMN were incubated with the vehicle alone (Fig. 9) or boiled TPO.

\section{Discussion}

TPO is considered a lineage-specific cytokine that regulates proliferation and maturation of committed cells leading to the production of megakaryocytes and platelets (3-7) and functionally activates mature platelets (8-10). The TPO receptor, $\mathrm{c}-\mathrm{Mpl}$, is expressed on cells of the megakaryocytic lineage from late progenitors to mature platelets (3-7) as well as on fetal liver cells, endothelial cells, and acute myeloblastic leukemia cells (1). In addition, recent data demonstrate that TPO is also able to stimulate proliferation and differentiation of erythroid progenitors (13) and the proliferation of blast cells from various types of acute myelogenous leukemia (38), suggesting that TPO may have a broad range of expression and bi-

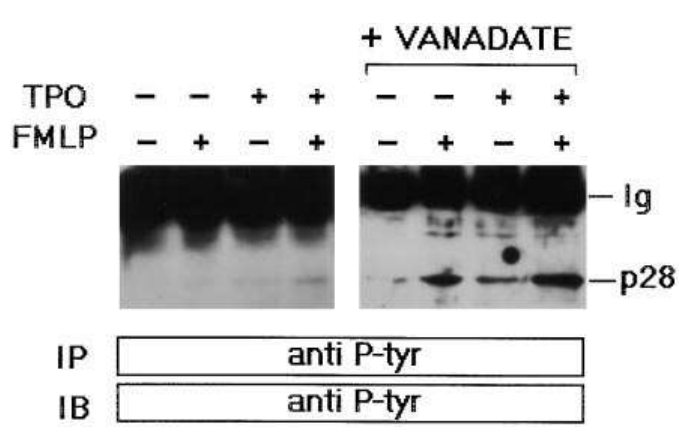

Figure 8. Effect of vanadate on p28 tyrosine phosphorylation. After $10 \mathrm{~min}$ of vanadate pretreatment $(200 \mu \mathrm{mol} / \mathrm{liter})$, cell lysates from unstimulated ( -$)$ and TPO- $(10 \mathrm{ng} / \mathrm{ml})$ or FMLP-stimulated (100 nmol/liter) (alone or in combination) $(+)$ PMN were immunoprecipitated with antiphosphotyrosine antibody. The filter was probed with 4G10 antiphosphotyrosine monoclonal antibody. The positions of the phosphotyrosine $\mathrm{p} 28$ are indicated. $I P$, immunoprecipitated; $I B$, immunoblotted; P-tyr, phosphotyrosine. ological activities. A large body of evidence indicates that TPO biological effects are mediated by a cascade of protein tyrosine phosphorylation including JAK2, STAT1, STAT3, and STAT5, Shc (19-24), and the p42 MAPK (8).

In this study, we investigated the expression of c-Mpl as well as the ability of TPO to induce both protein tyrosine phosphorylation and functional activation of human PMN. It has been shown that c-Mpl is abundantly expressed on platelets, whereas it is not detectable in peripheral blood mononuclear cells (31). Our study demonstrates that PMN, which have not been previously taken into consideration, clearly express c-Mpl.

PMN are terminally differentiated cells and do not undergo proliferation; however, tyrosine phosphorylation of intracellular molecules by different agonists seems to be involved in a number of functional activities such as superoxide anion production $(39,40)$, regulation of integrin surface expression leading to the adherence of PMN to endothelial cells, regulation of microvascular permeability, leading to migration of PMN into inflammatory tissue (41-44), and modulation of apoptotic process (45). Tyrosine phosphorylation of several peptides, including the oxidase known as p47phox, the MAPK, and the MAPKK, was increased in PMN stimulated with FMLP, leukotriene B4, phorbol ester, and A23187 (46, 47). Moreover, tyrosine phosphorylation of p93 ${ }^{\text {fes }}$, STAT1, and STAT3 as well as the formation of SIE complex containing both STAT1 and STAT3 have been reported in GM-CSF-stimulated PMN (27). It is known that activation of STAT proteins leads to the formation of dimers that migrate to the nucleus and form stable complexes with specific DNA sequences (response elements) and stimulate transcription (48). Three discrete complexes between activated STAT proteins and the serum inducible element (hSIE) of c-fos have been demonstrated upon EGF stimulation of A4131 cell proliferation (34). These complexes seem to be formed by STAT1 or STAT3 homodimers or by heterodimers composed by the two STATs (34). Similarly, TPOelicited mitogenic signaling leads to the induction of c-fos gene transcription through STAT1 and STAT3 activation (20). Our finding that, in TPO-stimulated terminally differentiated PMN, the SIE complex contained STAT1 but not STAT3 is consis- 

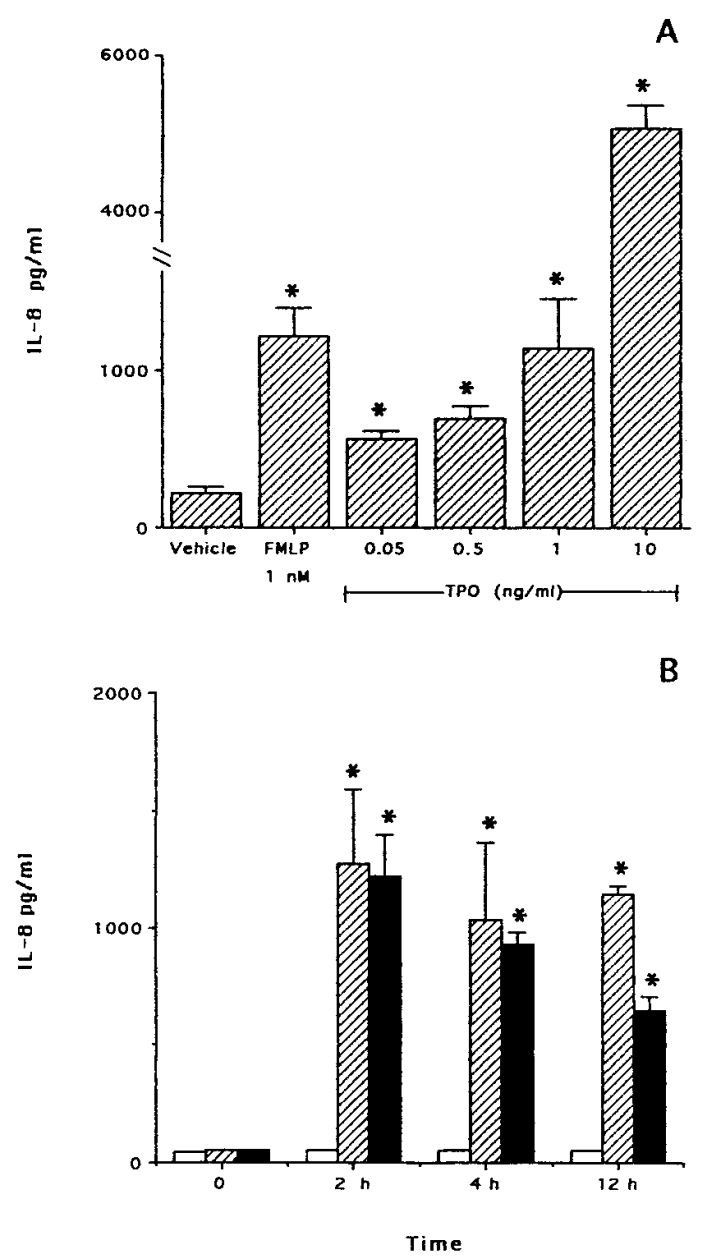

Figure 9. (A) Concentration-dependent effect of TPO on the release of IL- 8 by PMN. The assay was performed in duplicate on $1 \times 10^{6}$ $\mathrm{PMN}$ from the same donor. These results are representative of three experiments performed under the same conditions. $(B)$ Time course of IL-8 release by PMN stimulated with TPO or FMLP. $1 \times 10^{6}$ PMN were challenged with $0.05 \mathrm{ng} / \mathrm{ml}$ TPO or $1 \mathrm{nM}$ FMLP and IL- 8 was measured in the supernatant at various times by ELISA. Data are expressed as mean $\pm \mathrm{SE}$ of three individual experiments performed in duplicate. ANOVA with Dunnett's comparison test was performed within the experimental group of PMN incubated with vehicle alone (white bars) and the experimental groups of PMN incubated with TPO $(1 \mathrm{ng} / \mathrm{ml}$, striped bars $)$ or FMLP $(1 \mathrm{nM}$, black bars $)\left({ }^{*} P<0.05\right)$.

tent with the observations that a given growth factor can stimulate different STATs depending on the proliferation/differentiation state of the target cells $(24,49)$.

PMN play a critical role in nonspecific host defense by responding to chemoattractants leading to recruitment and accumulation of neutrophils at the inflammatory sites (50). The recruitment of PMN to inflammatory sites of infection is mediated by the production of a number of chemoattractant mediators (51). Among these, IL-8, which is produced by different cell types including PMN, differs from other chemoattractant mediators since it is highly selective for PMN migration into diseased tissues $(52,53)$. Moreover, the capability of chemotactically stimulated PMN to release IL-8 indicates that these cells may be able to amplify their recruitment process at the inflammatory sites (52). We found that TPO induced the release of IL-8, which unlike that induced by FMLP was still persistent after $12 \mathrm{~h}$ of stimulation, indicating a neosynthesis of the protein.

To kill invading microorganisms, PMN undergo an increase in their rate of oxygen consumption, known as respiratory burst (54). The respiratory burst can be activated by a variety of particulate and soluble stimuli such as opsonized zymosan, phorbol esters, bacterial chemotactic peptides including FMLP (54), and by some hemopoietic growth factors such as GM-CSF and G-CSF (15). In addition, GM-CSF and G-CSF not only exert direct effects on PMN functional activation (15) but also indirect effects such as priming the response of these cells to a number of physiological stimuli (15). This study shows that TPO, at variance with GM-CSF, is unable by itself to induce the respiratory burst but significantly enhanced this activity when PMN were subsequently stimulated with subthreshold concentrations of FMLP. This finding is in line with the recent demonstration that TPO by itself does not affect platelet aggregation but renders these cells more sensitive to other agonists (8-10).

In c-Mpl transfected cells, TPO specifically induces a rapid and brief tyrosine phosphorylation of a $28-\mathrm{kD}$ protein (55). We found that a protein with a similar molecular mass becomes tyrosine phosphorylated both in FMLP- and TPO-stimulated PMN and that, when TPO was added before FMLP, the p28 tyrosine phosphorylation was markedly increased. Although there is no evidence that this p28 is similar to that previously described in c-Mpl transfected cells (55), it is noteworthy that the tyrosine phosphorylation of a p28 may be involved in the signaling pathways of PMN functional activation. This hypothesis is supported by the observation that (a) vanadate determined a persistent increase of a p28 tyrosine phosphorylation and a marked potentiation of the priming effect of TPO on the release of $\mathrm{O}_{2}^{-}$by PMN stimulated with FMLP and (b) genistein abrogated the phosphorylation of the $\mathrm{p} 28$ protein (data not shown) and the priming effect of TPO.

In conclusion, the results of this study demonstrate that TPO induces in PMN STAT1 tyrosine phosphorylation and the formation of an SIE complex containing STAT1 and stimulates the activation of PMN by inducing IL- 8 release and by priming these cells to oxygen metabolite production. These data demonstrate that TPO may not only stimulate proliferation, differentiation, and functional activation of cells of the megakaryocytic lineage but may also enhance the antimicrobial defense by a direct action on PMN. It is known that the potent system evolved in PMN for the purpose of microbial killing can also produce and/or exacerbate both acute and chronic inflammatory states. Thus, the observation that TPO effects on PMN were obtained with physiological concentrations of TPO (56) may be taken into consideration in view of an in vivo therapeutic administration of this cytokine.

\section{Acknowledgments}

We thank Prof. Yosef Yarden for the generous gift of anti-STAT1 antiserum.

This work was supported by Associazione Italiana Ricerca sul Cancro (AIRC), by CNR, Progetti Finalizzati A.C.R.O., and F.A.T.M.A., and by ISS VII Progetto AIDS. P. Strippoli is a fellow of AIRC. 


\section{References}

1. Vigon, I., J.P. Mornon, L. Cocault, M.T. Mitjavila, P. Tambourin, S. Gisselbrecht, and M. Souyri. 1992. Molecular cloning and characterization of MPL, the human homolog of the v-mpl oncogene: identification of a member of the hematopoietic growth factor receptor superfamily. Proc. Natl. Acad. Sci. USA. 89:5640-5644.

2. Vigon, I., F. Dreyfus, J. Melle, F. Viguiè, V. Ribrag, L. Cocault, M. Souyri, and S. Gisselbrecht. 1993. Expression of the c-mpl proto-oncogene in human hematologic malignancy. Blood. 82:877-883.

3. Lok, S., K. Kaushansky, R.D. Holly, J.L. Kuijper, C.E. Lofton-Day, P.J. Oort, F.J. Grant, M.D. Heipel, S.K. Burkhead, J.M. Kramer, and D.C. Foster. 1994. Cloning and expression of murine thrombopoietin cDNA and stimulation of platelet production in vivo. Nature (Lond.). 369:565-568.

4. Kaushansky, K., S. Lok, R.D. Holly, V.C. Broudy, N. Lin, M.C. Bailey, J.W. Forstrom, M.M. Buddle, P.J. Oort, F.S. Hagen, and D.C. Foster. 1994. Promotion of megakaryocyte progenitor expansion and differentiation by the c-Mpl ligand thrombopoietin. Nature (Lond.). 369:568-571.

5. Wendling, F., E. Maraskovsky, N. Debili, C. Florindo, M. Teepe, M. Titeux, N. Methia, J. Breton-Gorius, D. Cosman, and W. Vainchenker. 1994. c-Mpl ligand is a humoral regulator of megakaryocytopoiesis. Nature (Lond.). 369:571-574

6. Bartkey, T.D., J. Vogenberger, P. Hunt, Y.S. Li, H.S. Lu, F. Martin, M.-S. Chang, B. Samal, J.L. Nichol, S. Swift, and R.A. Bosselman. 1994. Identification and cloning of a megakaryocyte growth and development factor that is a ligand for the cytokine receptor Mpl. Cell. 77:1117-1124.

7. Gurney, A.L., K. Carver-Moore, F.J. de Sauvage, and M.W. Moore. 1994 Thrombocytopenia in c-mpl-deficient mice. Science (Wash. DC). 265:14451447.

8. Montrucchio, G., M.F. Brizzi, G. Calosso, S. Marengo, L. Pegoraro, and G. Camussi. 1996. Effect of recombinant human megakaryocyte growth and development factor (Mgdf) on platelet activation. Blood. 87:2762-2768.

9. Fielder, P.J., A.L. Gurney, E. Stefanich, M. Marian, M.W. Moore, R. Carvermoore, and F.J. Desauvage. 1996. Regulation of thrombopoietin levels by c-mpl-mediated binding to platelets. Blood. 87:2154-2161.

10. Chen, J., L. Herceg-Harjacek, J.E. Groopman, and J. Grabare. 1995. Regulation of platelet activation in vitro by the c-Mpl ligand, thrombopoietin. Blood. 86:4054-4062.

11. Methia, N., F. Lowache, W. Vainchenker, and F. Wendling. 1993. Oligodeoxynucleotides antisense to the proto-oncogene c-mpl specifically inhibit in vitro megakaryocytopoiesis. Blood. 82:1395-1401.

12. Kaushansky, K., V.C. Broudy, A. Grossmann, J. Humes, N. Lin, H. Ping Ren, M.C. Bailey, T. Papayannopoulou, J.W. Forstrom, and K.H. Sprugel. 1995. Thrombopoietin expands erythroid progenitors, increases red cell production, and enhances erythroid recovery after myelosuppressive therapy. $J$. Clin. Invest. 96:1683-1687.

13. Kabayashi, M., J.H. Laver, T. Kato, H. Miyazaki, and M. Ogawa. 1995. Recombinant human thrombopoietin (Mpl ligand) enhances proliferation of erythroid progenitors. Blood. 86:2494-2499.

14. Clark, S.C., and R. Kamen. 1987. The human hematopoietic colonystimulating factors. Science (Wash. DC). 326:1229-1237.

15. Nathan, C.F. 1989. Respiratory burst in adherent human neutrophils: triggering by colony-stimulating factors CSF-GM and CSF-G. Blood. 73:301306

16. Arnaout, M.A., E.A. Wang, S.C. Clark, and C.A. Sieff. 1986. Human recombinant granulocyte-macrophage colony-stimulating factor increases cell to cell adhesion and surface expression of adhesion-promoting surface glycoproteins on mature granulocytes. J. Clin. Invest. 78:597-601.

17. Thelen, M., B. Dewald, and M. Baggiolini. 1993. Neutrophil signal transduction and activation of the respiratory burst. Physiol. Rev. 73:797-821.

18. Kishimoto, T., T. Taga, and S. Akira. 1994. Cytokine signal transduction. Cell. 76:253-262.

19. Sattler, M., M.A. Durstin, D.A. Frank, K. Okuda, K. Kaushansky, R. Salgia, and J.D. Griffin. 1995. The thrombopoietin receptor c-MPL activates JAK2 and TYK2 tyrosine kinases. Exp. Hematol. 23:1040-1048.

20. Gurney, A.L., S.C. Wang, W.J. Henzel, and F. de Sauvage. 1995. Distinct regions of c-MPL cytoplasmic domain are coupled to the JAK-STAT signal transduction pathway and Shc phosphorylation. Proc. Natl. Acad. Sci. USA. 92:5292-5296.

21. Miyakawa, Y., A. Oda, B.J. Druker, T. Kato, H. Miyazaki, M. Handa, and Y. Ikeda. 1995. Recombinant thrombopoietin induces rapid protein tyrosine phosphorylation of Janus Kinase 2 and Shc in human blood platelets. Blood. 86:23-27.

22. Tortolani, P.J., J.A. Johnston, C.M. Bacon, D.W. McVicar, A. Shimosaka, D. Linnekin, D.L. Longo, and J.J. O'Shea. 1995. Thrombopoietin induces tyrosine phosphorylation and activation of the Janus kinase, JAK2. Blood. 85: 3444-3451.

23. Morella, K.K., E. Bruno, S. Kumaki, C.F. Lai, J. Fu, H.M. Wang, L. Murray, R. Hoffman, M. Timour, L. Benit, et al. 1995. Signal transduction by the receptor for thrombopoietin (c-mpl) and interleukin-3 in hemopoietic and nonhemopoietic cells. Blood. 86:557-571.
24. Pallard, C., F. Gouilleux, L. Benit, L. Cocault, M. Souyri, D. Levy, B. Groner, S. Gisselbrecht, and I. Dusanter-Fourt. 1995. Thrombopoietin activates a STAT5-like factor in hematopoietic cells. EMBO (Eur. Mol. Biol. Organ.) J. 14:2847-2856.

25. Brizzi, M.F., M.G. Zini, M.G. Aronica, J.M. Blechman, Y. Yarden, and L. Pegoraro. 1994. Convergence of signaling by interleukin-3, granulocyte-macrophage colony-stimulating factor, and mast cell growth factor on JAK2 tyrosine kinase. J. Biol. Chem. 269:31680-31684.

26. Polatskaya, A., Y. Zhao, M.B. Lilly, and A.S. Kraft. 1994. Mapping the intracytoplasmic regions of the alpha granulocyte-macrophage colony-stimulating factor-receptor necessary for cell-growth regulation. J. Biol. Chem. 269: 4607-4613.

27. Brizzi, M.F., M.G. Aronica, A. Rosso, G.P. Bagnara, Y. Yarden, and L. Pegoraro. 1996. Granulocyte-macrophage colony-stimulating factor stimulates JAK2 signaling pathway and rapidly activates p93 ${ }^{\text {fes }}$, STAT1 p91 and STAT3 p92 in polymorphonuclear leukocytes. J. Biol. Chem. 271:3562-3567.

28. Sadowski, H.B., and M.Z. Gilman. 1993. Cell-free activation of a DNAbinding protein by epidermal growth factor. Nature (Lond.). 362:79-83.

29. Goldstein, I.M., D. Roos, H.B. Kaplan, and G. Weissmann. 1975. Complement and immunoglobulins stimulate superoxide production by human leukocytes independently of phagocytosis. J. Clin. Invest. 56:1155-1163.

30. De Luca, M.A., and W.D. McElroy. 1981. Bioluminescence and Chemiluminescence. Academic Press, New York.

31. Debili, N., F. Wendling, D. Cosman, M. Titeux, C. Florindo, I. Dusanter-Fourt, K. Schooley, N. Methia, M. Charon, R. Nador, et al. 1995. The $\mathrm{Mpl}$ receptor is expressed in the megakaryocytic lineage from late progenitors to platelets. Blood. 85:391-401.

32. Kabayashi, M., J.H. Laver, T. Kato, H. Miyazaki, and M. Ogawa. 1996. Trombopoietin supports proliferation of human primitive hematopoietic cells in synergy with steel factor and/or interleukin-3. Blood. 88:429-436.

33. Farese, A.M., P. Hunt, L.B. Grab, and T.J. Macvittie. 1996. Combined administration of recombinant human megakaryocyte growth and development factor and granulocyte colony-stimulating factor enhances multilineage hematopoietic reconstitution in nonhuman primates after radiation-induced marrow aplasia. J. Clin. Invest. 97:2145-2151.

34. Zhong, Z., Z. Wen, and J.E. Darnell, Jr. 1994. Stat3: a STAT family member activated by tyrosine phosphorylation in response to epidermal growth factor and interleukin-6. Science (Wash. DC). 264:95-98.

35. Grinstein, S., W. Furuya, D.J. Lu, and G.B. Millis. 1990. Vanadate stimulates oxygen consumption and tyrosine phosphorylation in electropermeabilized human neutrophils. J. Biol. Chem. 265:318

36. Trudel, S., M.R. Paquet, and S. Grinstein. 1991. Mechanism of vanadate-induced activation of tyrosine phosphorylation and respiratory burst in HL60 cells. Biochem. J. 276:611-619.

37. Rollet, E., A.C. Caon, C.J. Roberge, N.W. Liao, S.E. Malawista, S.R McColl, and P.H. Naccache. 1994. Tyrosine phosphorylation in activated human neutrophils. J. Immunol. 153:353-363.

38. Matsumura, I., Y. Kanakura, T. Kato, H. Ikeda, J. Ishikawa, Y. Horikawa, K. Hashimoto, Y. Moriyama, T. Tsujimura, T. Nishiura, et al. 1995. Growth response of acute myeloblastic leukemia cells to recombinant human thrombopoietin. Blood. 86:703-709.

39. Cui, Y., K. Harvey, L. Akard, J. Jansen, C. Hughes, R.A. Siddiqui, and D. English. 1994. Regulation of neutrophil responses by phosphotyrosine phosphatase. J. Immunol. 152:5420-5428.

40. McColl, S.R., J.F. DiPersio, A.C. Caon, P. Ho, and P.H. Naccache. 1991 Involvement of tyrosine kinases in the activation of human peripheral blood neutrophils by granulocyte-macrophage colony-stimulating factor. Blood. 78: 1842-1852.

41. Naccache, P.H., C. Gilbert, A.C. Caon, M. Gaudry, C.-K. Huang, V.A. Bonak, K. Umezawa, and S.R. McColl. 1990. Selective inhibition of human neutrophils responsiveness by erbastatin, an inhibitor of tyrosine protein kinase. Blood 76:2098-2104.

42. Berkow, R.L, and R.W. Dodson. 1990. Tyrosine-specific protein phosphorylation during activation of human neutrophils. Blood. 75:2445-2452.

43. Worhten, G.S., N. Avdi, A.M. Buhl, N. Suzuki, and G.L. Johnson. 1994 FMLP activates Ras and Raf in human neutrophils. J. Clin. Invest. 94:815-823.

44. Kubes, P., M. Suzuki, and D.N. Granger. 1990. Modulation of PAFinduced leukocyte adherence and increased microvascular permeability. Am. J. Physiol. 259:G859-G864.

45. Yousefi, S., D.R. Green, K. Blaser, and H.-U. Simon. 1994. Protein tyrosine phosphorylation regulates apoptosis in human eosinophils and neutrophils. Proc. Natl. Acad. Sci. USA. 91:10868-10872.

46. Lu, D.J., W. Furuya, and S. Grinstein. 1993. Involvement of multiple kinases in neutrophil activation. Blood Cells. 19:343-351.

47. Bokoch, G.M. 1995. Chemoattractant signaling and leukocyte activation. Blood. 86:1649-1660.

48. Darnel, J.E., Jr., I.M. Kerr, and J.R. Stark. 1994. JakSTAT pathways and transcriptional activation in response to IFNs and other extracellular signaling proteins. Science (Wash. DC). 264:1415-1421.

49. Azam, M., H. Erdjument-Bromage, B.L. Kraider, M. Xia, F. Quelle, R. Basu, C. Saris, P. Tempst, J.N. Ihle, and C. Schindler. 1995. Interleukin-3 signal through multiple isoforms of STAT5. EMBO (Eur. Mol. Biol. Organ.) J. 14: 
1402-1411.

50. Sha'afi, R.I., and T.F.P. Molski. 1988. Activation of the neutrophils. Prog. Allergy. 42:1-64.

51. Wilkinson, P.C. 1982. Chemotaxis and Inflammation. Churchill Livingston, Edinburgh

52. Cassatella, M.A., F. Bazzoni, M. Ceska, I. Ferro, M. Baggiolini, and G. Berton. 1992. IL-8 production by human polymorphonuclear leukocytes. J. Immunol. 148:3216-3220.

53. Baggiolini, M., B. Moser, and I. Clark-Lewis. 1994. Interleukin- 8 and related chemotactic cytokines. Chest. 105:95s-98s.

54. Baggiolini, M., and P. Kernen. 1992. Neutrophil activation: control of shape change, exocytosis and respiratory burst. News Physiol. Sci. 7:215-219.

55. Mu, S.X., M. Xia, G. Elliott, J. Bogenberger, S. Swift, L. Bennet, D.L. Bennett, D.L. Lappinga, R. Hecht, R. Lee, and C.J.M. Saris. 1995. Megakaryocyte growth and development factor and IL-3 induce patterns of protein tyrosine phosphorylation that correlate with dominant differentiation over proliferation of mlp-transfected 32D cells. Blood. 86:4532-4543.

56. Nichol, J.L., M.M. Hokom, A. Hornkohl, W.P. Sheridan, H. Ohashi, T. Kato, Y.S. Li, T.D. Bartley, E. Choi, J. Bogenberger, and P. Hunt. 1995. Megakaryocyte growth and development factor analysis of the in vitro effects on human megakaryopoiesis and endogenous serum levels during chemotherapyinduced thrombocytopenia. J. Clin. Invest. 95:2973-2978. 